Paweł Dybel

Instytut Filozofii i Socjologii PAN, Warszawa

e-mail: pdybel@ifispan.waw.pl

\title{
Człowiek, zwierzę i zwierciadło. Genealogia ludzkiego Ja według Helmutha Plessnera i Jacquesa Lacana
}

DOI: http://dx.doi.org/10.12775/RF.2017.023

W eseju Jak porównywać zachowania ludzkie i zwierzęce Helmuth Plessner przytacza znane doświadczenie Köhlera, który obserwował zachowania młodego szympansa i małego dziecka przed lustrem. Okazało się, że jakkolwiek szympans reagował na swe lustrzane odbicie, rozpoznawał w nim tylko osobnika swojego gatunku, a nie siebie, podczas gdy dziecko było w stanie zidentyfikować to odbicie jako obraz własny. Opisując to doświadczenie, Plessner zastanawia się nad tym, skąd wzięła się ta różnica i dochodzi do wniosku, że człowiek w odróżnieniu od zwierząt posiada wyobrażenie siebie jako indywidualnego Ja. To wyobrażenie zakorzenione jest w sposobie, $\mathrm{w}$ jaki odnosi się do innych, który określa „wymienialność punktów widzenia wyznaczających perspektywę" ${ }^{1}$ tkwiącą u podstawy wszelkich związków społecznych.

Owa wymienialność polega na tym, że człowiek może wyobrazić siebie jako jedno $\mathrm{z}$ wielu Ja, potencjalnie zastępowalne przez inne Ja. Zarazem jednak wie, że ta możliwość jest praktycznie nie do urzeczywistnienia. Inny może wprawdzie zająć miejsce, w którym się znajduję, może przejąć różne moje role i funkcje zawodowe, społeczne itd. Nie może jednak stać się mną samym; utożsamić się z moim Ja. Dzieje się tak dlatego, ponieważ jednostka ludzka, wchodząc w role społeczne „wymienialne" z innymi, ma możliwość wycofania się w siebie. Dzięki

1 H. Plessner, Jak porównywać zachowania ludzkie i zwierzęce, w: idem, Pytanie o conditio humana, przeł. Z. Krasnodębski, A. Załuska i in., Warszawa 1988, s. 236. 
niej zaś: „zajmuje ona pewne miejsce, absolutne »tutaj«, i mimo zmian sytuacji potrafi niezmiennie identyfikować innego"². Tym samym zaś doświadcza siebie jako „niewymienialną” (unverwechselbar), czyli jako taka, która nie daje się w tym, co stanowi o niej jako indywidualnym Ja, zastąpić przez innego.

Zgodnie z tym ujęciem możliwość wycofania się w siebie pozwala człowiekowi zdystansować się wobec wszelkich ról społecznych, otwierając go na indywidualny wymiar jego własnego istnienia, który autor Conditio humana nazywa "osobowością" (die Persönlichkeit). Drugą stroną społecznych związków człowieka z innymi jest poczucie indywidualnej tożsamości, zakorzenione $\mathrm{w}$ jego zdolności do wycofania się $\mathrm{w}$ siebie. W wyniku tego może on zdobyć się na uprzedmiotowiający dystans wobec własnego ciała i wobec innych, do czego niezdolne są zwierzęta.

Jest to sytuacja paradoksalna. Właśnie dlatego, że człowiek może wyobrazić sobie, iż ktoś inny mógłby znaleźć się na jego miejscu, odkrywa on, że jako ,jeden z wielu" jest niezastępowalny w swej jednostkowości. Poczucie własnej indywidualności staje się możliwe dopiero na gruncie wyobrażenia siebie jako wymienialnego z innymi Ja. Paradoks ten zasadza się na tym, że człowiek, wyobrażając siebie jako jednego z wielu, może uzyskać dystans do siebie i zdać sobie sprawę z tego, że jest niezastępowalny w swoim indywidualnym Ja. Dlatego człowiek, patrząc na swój obraz w lustrze, widzi w nim siebie jako niezastępowalnego w swym Ja i jest w stanie odróżnić je od innych Ja. Zwierzę natomiast, nie mogąc wyobrazić siebie jako ,jednego z wielu" o indywidualnej osobowości, nie może uzyskać tego rodzaju dystansu do siebie, pozwalającego mu na identyfikację własnego obrazu jako różniącego się od obrazów innych. Kiedy spogląda w lustro, nie widzi w nim „,siebie”, lecz tylko „innego" jako przedstawiciela własnego gatunku.

Rzecz ciekawa, że do tego samego doświadczenia Köhlera nawiązuje we wczesnym okresie francuski psychoanalityk Jacques Lacan, formułując na jego podstawie teorię „stadium lustra”. Zwraca on jednak uwagę na inne aspekty tego doświadczenia, inne też są jego konkluzje w kwestii rozumienia podstaw ludzkiej tożsamości ${ }^{3}$.

Kluczowe znaczenie w interpretacji tego doświadczenia przez Lacana ma - pominięty w rozważaniach Plessnera - radosny okrzyk dziecka „Aha!" wydany przez nie w konfrontacji z własnym lustrzanym obrazem:

2 Ibidem, s. 291.

3 Koncepcję "stadium lustra" Jacques Lacan sformułował w artykule Le stade du mirroir, który później wszedł w skład Ecrits (por. J. Lacan, Ecrits, Paris 1960, s. 93-101). 
Akt ten, nie wyczerpujący się - jak u małpy - w rozpoznaniu ułudności obrazu, przeradza się natychmiast u dziecka w serię gestów, w której ludycznie doświadcza ono związków między swoimi ruchami ukazanymi w obrazie a odbiciem otoczenia oraz związków całego tego potencjalnego kompleksu spostrzeżeń z rzeczywistością odbijaną w lustrze, zarówno swojego ciała, jak i osób i przedmiotów, które są koło niego ${ }^{4}$.

Dziecko zatem po ujrzeniu swego obrazu w lustrze zdradza wyraźną nim fascynację, która utrzymuje się przez dłuższy czas. Natomiast szympans, po tym, jak nie znalazł za lustrem „innego" przedstawiciela gatunku, którego widział, traci zainteresowanie dla swego lustrzanego odbicia. Lacan, którego zaintrygowała ta różnica w reakcjach dziecka i szympansa, stara się w swoim artykule dać odpowiedź na pytanie, skąd wzięła się owa fascynacja dziecka. W swej argumentacji autor Écrits sięga do ustaleń w dziedzinie ludzkiej anatomii i biologii, do których również nawiązywał - za Maxem Schelerem - Plessner w swojej antropologii filozoficznej. Zgodnie z nimi dzieci ludzkie - inaczej niż potomstwo ssaków - przychodzą na świat „za wcześnie”, będąc zrazu nieprzystosowane do życia w obcym im środowisku. Według Plessnera jednak zdolność człowieka do postawienia siebie w miejscu innego sprawia, że dziecko bardzo szybko nadrabia ten brak. Jest ono bowiem w stanie inaczej niż zwierzęta - w sposób instrumentalny potraktować własne ciało i rzeczy z najbliższego otoczenia, zdobywa też z czasem pierwsze kompetencje językowe, które pozwalają mu poszerzyć gamę tego rodzaju zachowań itd. Zgodnie z tym ujęciem o różnicy między człowiekiem i zwierzęciem stanowi zdolność człowieka do abstrakcyjnego myślenia. Dzięki niej może on w sposób przedmiotowy odnosić się do różnych obszarów bytu (łącznie z własnym ciałem), wytwarzać narzędzia i czynić je elementem swego społecznego bytu $z$ innymi. Ten wątek $w$ refleksji o korzeniach człowieczeństwa jako „wybrakowanego" w porównaniu $\mathrm{z}$ uposażeniem zwierząt, który w filozofii znalazł swój wymowny wyraz w twierdzeniu Herdera, że człowiek jest „inwalidą swoich wyższych sił” (czy w słynnym powiedzeniu Nietzschego, że człowiek jest „chorym zwierzęciem"), podejmuje też później Plessner w swoich pracach ${ }^{5}$.

Lacan natomiast, nawiązując do współczesnych naukowych teorii z dziedziny biologii i antropologii, w których mówi się o wcześniactwie

4 J. Lacan, Stadium lustra, przeł. J. Aleksandrowicz, „Psychoterapia”, 1987, nr 4, s. 5 .

5 W Pytaniu o conditio humana Plessner, powołując się na Herdera, pisze na przykład: „Nie mamy pazurów i rogów, nie mamy jadu ani ostrych zębów, nie mamy ochronnego futra. Nasze instynkty są zbyt słabe, aby kierować naszym życiem. Czy jako istoty wybrakowane, bo niedostatecznie wyposażone [...] otrzymaliśmy tytułem rekompensaty inteligencję, język i zdolność abstrakcji?" (H. Plessner, Pytanie o conditio humana, w: idem, Pytanie o..., op. cit., s. 80-81). 
człowieka, zwraca uwagę na pominięty w nich psychologiczny aspekt tego wcześniactwa. Twierdzi, że związany ze zbyt wczesnym przyjściem ludzkiego dziecka na świat brak koordynacji jego ruchów, niemożność zapanowania nad procesami wydalniczymi itd. ma swój psychologiczny odpowiednik w odczuwaniu przez nie własnego ciała jako pokawałkowanego czy rozerwanego. Dziecko produkuje wówczas przesycone agresją fantazje, w których na różne sposoby daje wyraz owemu poczuciu. Ponadto:

To porozrywane ciało [...] pojawia się regularnie w snach, wówczas, gdy proces analizy, docierając do określonego poziomu, dotyka problemu aktywnej dezintegracji jednostki. Pojawia się ono wtedy w formie oddzielnych kończyn i innych organów widzianych z zewwnątrz, uskrzydlonych, uzbrojonych przeciwko wewnętrznym prześladowaniom, które utrwalił w swoich obrazach malarz-wizjoner Hieronim Bosch, wznosząc się ponad wiek piętnasty do zenitu wyobraźni człowieka współczesne$\mathrm{go}^{6}$.

Na tym nie koniec tych pokrewieństw i analogii. Zachodzi bowiem zdumiewające pokrewieństwo między wczesnym dziecięcym doświadczeniem własnego ciała $\mathrm{w}$ wieku niemowlęcym a analogicznymi fantazjami i zachowaniami psychotyków. Wymownym tego świadectwem miał być słynny przypadek mordu na pani domu i jej córce dokonanego przez dwie służące, siostry Papin ${ }^{7}$. Skarcone za zaniedbanie prac domowych wpadły w furię, mordując właścicielki ze szczególnym okrucieństwem (wydzierając im oczy oraz masakrując ciała na drobne części). W ujęciu Lacana to szaleńcze zachowanie obu sióstr było wynikiem nagłego wybuchu u nich psychozy. Był to typowy passage a acte, polegający na nagłym uzewnętrznieniu się $\mathrm{w}$ ich zachowaniu sił destrukcji i agresji, skumulowanych $w$ ich psychice pod wpływem traumatycznych wydarzeń z dzieciństwa.

Zachowanie sióstr Papin można tłumaczyć jako wynik regresu na wczesny etap psychicznego rozwoju, który znamionują fantazje o pokawałkowaniu własnego ciała. $\mathrm{O}$ „archetypicznym” i uniwersalnym charakterze tych fantazji świadczą według Lacana wymownie różne zjawiska z dziedziny sztuki, jak "psychotyczne” malarstwo wspomnianego Boscha czy Salvadora Dali. W podobnym kierunku tworzyła swoją koncepcję rozwoju ludzkiej psychiki Melanie Klein, która stwierdziła dominację popędów Tanatosa $\mathrm{w}$ ramach wczesnej pozycji schizo-para-

6 J. Lacan, Stadium..., op. cit., s. 7.

Na tego typu przypadku oparł Lacan temat swojej rozprawy doktorskiej pt. De la psychose paranoiaque dans ses rapports avec la personnalite, Paris 1932. Szerzej na ten temat pisze Elisabeth Roudinesco w monografii o Lacanie por. E. Roudinesco, Jacques Lacan. Jego życie i myśl, przeł. R. Reszke, Warszawa 2005, s. 97-123. 
noidalnej dziecka. W tym okresie bowiem czuje się ono prześladowane przez „złą pierś”, którą traktuje jako odrębną w stosunku do „dobrej piersi" matki, nie będąc w stanie powiązać jej z jednolitym obrazem ciała jej osoby. Odpowiada temu po jego stronie brak wyraźnego poczucia własnego Ja.

Jakkolwiek w antropologii Plessnera teza o ludzkim wcześniactwie odgrywa ważką rolę, koncentruje się on na wspomnianych kompensacyjnych zdolnościach dziecka związanych z jego zdolnością do abstrakcyjnego myślenia (zdystansowanie się do własnego ciała oraz do świata na zewnątrz, wypowiadanie pierwszych słów itd.). To dzięki tym zdolnościom do „nietypowych” dla świata zwierzęcego zachowań człowiek może potraktować własne ciało jako „futerał”, może też uprzedmiotowiać własne relacje społeczne. Traktuje on wówczas własne Ja jako z jednej strony potencjalnie wymienialne $\mathrm{z}$ innymi Ja, z drugiej zaś otwierające przed nim możliwość wycofania się w siebie. Pozwala mu to zdać sobie sprawę z własnej indywidualnej niezastępowalności.

Lacan natomiast uznaje, że różnica między sposobem, w jaki człowiek i zwierzę odnoszą się do lustrzanego obrazu własnego ciała zaznacza się $\mathrm{w}$ fascynacji dziecka własnym lustrzanym obrazem. Ponieważ młode osobniki z grupy wyższych ssaków są w momencie przyjścia na świat nieźle przystosowane do funkcjonowania w najbliższym otoczeniu (koordynacja ruchów ciała, szybkie opanowanie procesów wydalniczych itd.), jednolity obraz ich własnego ciała ujrzany w lustrze nie robi na nich szczególnego wrażenia. Natomiast ludzkie dziecko, odczuwając przez długi czas własne ciało jako chaos różnych procesów i funkcji, odnajduje w jego lustrzanym odbiciu, w którym owo ciało prezentuje mu się jako upragniona idealna jedność, poszukiwaną przez siebie przeciwwagę dla tego nieznośnego poczucia. Nic dziwnego, że ulega ono „przesadnej” fascynacji swoim lustrzanym obrazem innego-siebie, który od tej pory stanie się podstawą do ukształtowania się jego wyobrażenia siebie jako Ja.

Rolę takiego obrazu ciała, który staje się źródłem fascynacji dziecka, może jednak w równej mierze spełnić obraz ciała kogoś innego, np. matki. Dziecko traktuje wówczas ów obraz tak, jakby był to obraz jego własnego ciała. Jakkolwiek posiada ono już poczucie indywidualności swego Ja, to nie jest jeszcze w stanie odróżnić wyraźnie lustrzanych obrazów innego-siebie od obrazów ciał innych. Te ostatnie traktuje tak, jakby były to obrazy jego ciała, o czym świadczy wymownie tranzytywizm dziecięcy. Z jego perspektywy liczy się przede wszystkim obraz idealnej jedności siebie, obojętnie, czy należy on do niego samego, czy do kogoś innego. Lacan pierwotną formę tego obrazu nazywa "Ja idealnym" (je-ideal), uznając, że: 
forma ta, sytuująca instancję ego w planie fikcji, jeszcze przed jej społecznym określeniem, nie da się zredukować tylko do tego, co jest samą jednostką - raczej może jedynie asymptomatycznie zmierzać do stania się podmiotem $[\ldots]^{8}$.

„Ja idealne" ma status wyobrażeniowej fikcji, w rzeczywistości nic mu nie odpowiada. Jednakże dzięki temu dziecko odnajduje w nim upragnioną przeciwwagę dla nękającego je poczucia chaosu. Od tej pory obraz idealnej jedności siebie będzie dlań stanowił główny punkt odniesienia w dalszym rozwoju jego osobowości w kontaktach z innymi.

To że dziecko nie jest jeszcze w stanie wyraźnie odróżnić lustrzanego obrazu siebie od obrazów ciał innych, nie przeszkadza temu, że posiada ono już poczucie indywidualności swego Ja. Nawet jeśli dziecko myli się co do tego, do kogo należy ujrzany przez nie obraz, kluczowe znaczenie posiada jego fascynacja tym obrazem, tak jakby był to obraz jego samego. Druga, nieodłączną stroną fascynacji własnym obrazem jest agresja dziecka w stosunku do niego. Ujawnia się ona w momencie, kiedy dziecko spostrzega, że „coś tu jest nie tak”. Wykonuje ruch ręka, a tamten z lustra robi to samo tylko w przeciwną stronę, poza tym, jest jakby mniejszy itd. Proces ten świadczy zarazem o tym, że dziecko zaczyna doświadczać różnicy między lustrzanym obrazem siebie a soba, jakkolwiek nie zdaje sobie jeszcze z tego sprawy. To zaś implikuje, że jest ono w stanie zdystansować się do tak obsadzonego narcystycznie obrazu innego-siebie. Możliwość uzyskania dystansu w relacji do siebie (co zakłada autorefleksyjną strukturę jaźni) i narcyzm są tu ze sobą powiązane. Bez „zakochania się" w innym sobie dziecko nie byłoby w stanie powrócić do siebie i pomyśleć o sobie jako Ja.

Jeśli dla Plessnera ruch wycofania się w siebie ludzkiego Ja stanowi efekt zdystansowania się wobec persony zaangażowanej $w$ relacje wzajemnej wymienności z innymi, dla Lacana ten ruch może pojawić się dopiero $\mathrm{w}$ wyniku zdystansowania się Ja wobec poprzedzającego te relacje narcystycznego zauroczenia idealnym obrazem innego siebie. Jeśli ludzkie Ja nie „zakocha się" w sobie i nie rozpozna swej pomyłki, zdobywając się na dystans wobec własnego idealnego Ja, nie będzie ono w stanie wejść w relacje wzajemności z innymi. Narcystyczne zatracenie się na płaszczyźnie lustrzanego obrazu siebie stanowi etap początkowy, dopiero później może pojawić się zdystansowanie się wobec siebie i otwarcie na innych. Dlatego przepojone narcyzmem odniesienie do obrazu siebie nie jest błędną drogą rozwoju ludzkiej tożsamości, ale stanowi warunek ukonstytuowania się wyobrażenia siebie jako Ja.

Zrazu jednak ta idealna postać Ja jest w oczach dziecka nieokreślona. Obraz „siebie”, który widzi ono w lustrze, to obraz tego, kim chciałoby

8 J. Lacan, Stadium..., s. 6. 
ono być. To inny jego samego, niedościgniony pierwowzór, któremu będzie starało się od tej pory dorównać. W Lacanowskiej teorii „stadium lustra" wcześniejsza formuła Freuda, że Ja to efekt projekcji obrazu ciała zyskuje nowy sens ${ }^{9}$. Owa projekcja nie jest wynikiem spontanicznej aktywności ludzkiej jednostki, ale ma postać ucieczki przed trudnym do zniesienia „obrazem” własnego ciała, który dziecko doświadcza po „tej” stronie lustra. Obraz ten nie odnosi się do tego, co dziecko postrzega na zewnątrz, ale wyrasta z wnętrza jego własnego ciała, obrastając w paranoiczne fantazje zniszczenia i śmierci.

\section{2.}

W obliczu odmiennych ujęć przez Plessnera i Lacana funkcji, jaką wyobrażenie siebie jako Ja pełni w ludzkim rozwoju, pojawia się pytanie o określenie statusu ontologicznego Ja w obu koncepcjach. Według Plessnera człowieka od innych stworzeń różni to, że jest osoba, która - jak powiada Kant - wśród innych wyobrażeń może mieć wyobrażenie Ja. To ostatnie zaś: „oznacza wyróżniony obszar, który zajmuję swoim ciałem, z którego widzę i działam"10.

I nieco dalej dodaje: „sens tego słowa odsłania się przed dzieckiem dopiero po paru latach dzięki wyrażeniom językowym. Dopiero później zaczyna rozumieć, że Ja oznacza źródło jego własnych działań, możliwość wycofania się »w głąb samego siebie«, a tym samym możliwość obarczania go odpowiedzialnością"11.

Zgodnie z tym ujęciem właściwe człowiekowi wyobrażenie siebie jako Ja ma status wyróżniony w stosunku do innych wyobrażeń. Wynika to stąd, że człowiek z wyobrażeniem siebie jako Ja wiąże swoje przebywanie w jakimś „tutaj”, w którym mogłoby się równie dobrze znaleźć inne Ja. To z kolei zakłada, że człowiek, wyobrażając siebie jako Ja, jest w stanie zdystansować się wobec siebie. Tylko wówczas może on wyobrazić sobie na swoim miejscu jakieś inne Ja. Innymi słowy, tylko dlatego, że w swym wyobrażeniu siebie jako Ja człowiek odnosi się do siebie jako do swego „innego", wymienialnego z innymi Ja, może on wyobrazić sobie, że miejsce jego własnego „innego" zajmuje jakieś inne Ja.

$\mathrm{Z}$ autorefleksyjną strukturą wpisaną $\mathrm{w}$ wyobrażenie siebie jako Ja wiąże się „zwierciadlany stosunek”, w jakim człowiek/Ja pozostaje z innymi w przestrzeni społecznej. Plessner nazywa ten stosunek „strukturą

9 Por. S. Freud, "Ja" i "to”, w: idem, Psychologia nieświadomości, przeł. R. Reszke, s. 224.

10 H. Plessner, Aspołeczna towarzyskość. Uwagi do pewnego pojęcia Kanta, przeł. Z. Krasnodębski, w: idem, Pytanie o..., op. cit., s. 288.

11 Ibidem. 
wzajemności”, twierdząc, że ma ona korzenie w osobowości: „Na razie najważniejsza jest tylko struktura wzajemności ugruntowana w osobowości jako takiej, struktura, która jedną osobę przyporządkowuje ściśle drugiej, bez względu na to, czym ona jest i co posiada ${ }^{12 "}$.

Dzięki tej strukturze jedna osoba, wyobrażając siebie jako Ja jest przyporządkowana innej/innym (innemu/innym Ja) w przestrzeni społecznej. W wyobrażeniu siebie przez człowieka jako Ja zawarte jest już odniesienie do innych Ja, które mogą zająć jego miejsce. Wyobrażenie to z racji określającej je "struktury wzajemności" tkwi u podstaw bytu społecznego człowieka. I jakkolwiek Ja mogę równie dobrze zająć miejsce innego Ja i grać jego społeczną rolę, to w rzeczywistości może się to udać tylko jednemu z nas. Innymi słowy dlatego, że inny może zająć moje miejsce, jest on w stanie mnie zdominować. I to właśnie dlatego, że nie zajmuje tego miejsca $\mathrm{w}$ sensie dosłownym, ale $\mathrm{w}$ przenośnym (w moim wyobrażeniu). $\mathrm{Z}$ tą pierwszą sytuacją mamy do czynienia jedynie wówczas, kiedy inny mnie zabija. Jest to jednak równoznaczne z unicestwieniem „struktury wzajemności” określającej nasz stosunek do siebie jako Ja. Uznanie dominacji innego przez Ja następuje dopiero dzięki zakorzenionej $\mathrm{w}$ doświadczeniu wzajemności perspektyw możliwości Ja wycofania się w siebie. Tylko wycofując się w siebie, Ja może uznać dominację innego w przestrzeni społecznej. Tego rodzaju zdystansowania się wobec siebie wymaga akt uznania czyjejś dominacji, obcy światu zwierzęcemu. Dominację innego mogę uznać jedynie jako Ja, które w akcie uznania - jako wycofane w siebie - określiło własne odniesienie do innego. Tym samym zaś, uznając dominację innego Ja, nigdy się do niej nie sprowadza. Zawsze pozostaje w nim możliwość wyboru innego odniesienia do innego i do siebie.

Dlatego przyporządkowanie Ja innemu Ja, o którym mówi Plessner jako nieuchronnym efekcie „wzajemności perspektyw”, niekoniecznie musi oznaczać uzależnienie Ja od innego. $Z$ tej samej racji człowiek może jako Ja wystąpić przeciwko dominacji innego. Jako „wycofany w siebie" nigdy nie wyczerpuje się - jako Ja - w uznaniu owej dominacji. Podobnie Ja, jako indywidualne Ja, nigdy nie mogę być pewien trwałego charakteru mojej dominacji nad innymi. Uznając moją dominację, inni zawsze moga podważyć swój akt uznania. Istnienie takiej możliwości jednak - a wypływa ona w sposób istotowy ze „struktury wzajemności" - nadaje wszelkim aktom uznania czyjejś dominacji w przestrzeni społecznej szczególną wartość, nieporównywalną z tym, co zwykło się nazywać dominacją w świecie zwierzęcym.

12 Ibidem. 
3.

W jednym punkcie Lacan jest bez wątpienia zgodny z Plessnerem. Ja to wyobrażenie siebie, dla którego źródłowy „pierwowzór" stanowi lustrzany obraz własnego ciała, z którym człowiek się identyfikuje. Obu łączy również przekonanie, że wyobrażenie to ma charakter wyróżniony ze względu na swoją strukturę. Obydwaj jednak przyznają wyobrażeniu Ja inny status ontologiczny.

Dla Plessnera wyobrażenie siebie jako Ja zjawia się w sposób naturalny na wczesnym etapie rozwoju człowieka i od tej pory określa jego relację do siebie, do innych i do świata. Podobnie jest u Kanta i w całej nawiązującej do niego filozoficznej tradycji. Wyobrażenie/pojęcie Ja traktowane jest tu jako ściśle powiązane z autorefleksyjną strukturą ludzkiej świadomości, w pewnym sensie uzasadnia ono samo siebie.

W horyzoncie filozofii Kanta mieści się również twierdzenie Plessnera o „wzajemności perspektyw”, którą implikuje sposób, w jaki ludzkie Ja odnosi się do innych. Źródłem inspiracji dla autora Pytania o conditio humana jest formuła „, aspołecznej towarzyskości”, za pomocą której Kant oddaje ambiwalencję odniesienia człowieka do innych. Nowym momentem jest wskazanie na powiązanie pojawienia się wyobrażenia Ja z wykształceniem kompetencji językowych przez dziecko. Niemniej jednak wypowiedzi Plessnera w tej materii mają charakter oderwany, często są ogólnikowe.

Ostatecznie w ujęciu Plessnera ludzkie Ja jest autonomiczną instancją w obrębie świadomości, która posiada autorefleksyjną strukturę. Dzięki temu stosunek człowieka do innych określa wymienność perspektyw, która tkwi u podstaw jego bytu społecznego.

Lacan z kolei proces kształtowania się ludzkiego Ja wiąże z sytuacją w której dziecko skonfrontowane z odczuwaniem własnego ciała jako pokawałkowanego ulega fascynacji jego fikcyjnym lustrzanym odbiciem, rozpoznając $w$ nim upragnioną idealną jedność samego siebie. Dziecko jest zafascynowane tym obrazem, gdyż znajduje $\mathrm{w}$ nim przeciwwagę dla trudnego do zniesienia schizofrenicznego poczucia pokawałkowania własnego ciała. Ujęcie to zakłada, że podobnie bolesne poczucie "chaosu" własnego ciała jest warunkiem możliwości fascynacji dziecka własnym idealnym pierwowzorem Ja i utożsamienia się z nim.

Inaczej niż dla Plessnera (czy Kanta) w oczach Lacana właściwe człowiekowi wyobrażenie siebie jako (idealnego) Ja nie zjawia się samo $\mathrm{z}$ siebie. Ja nie jest posiadającą uzasadnienie $\mathrm{w}$ sobie samej idealną formą ludzkiej świadomości siebie, nazwaną przez Kanta „transcendentalną jednością apercepcji", która towarzyszy wszelkim przedstawieniom. Forma ta może ukonstytuować się $\mathrm{w}$ tej postaci dopiero na podłożu doświadczenia przez jednostkę własnego ciała jako pokawałkowanego. 
W ujęciu Lacana wyobrażenie Ja idealnego pojawia się w wyniku czynności obronnej ze strony jednostki, jej dążenia do przeciwstawienia się niszczącemu ją doświadczeniu chaosu siebie. Dlatego:

formacja $j a$ jest onirycznie symbolizowana obrazem fortecy lub boiska, którego teren jest ogrodzony od zewnętrznego obszaru, oddzielony od otaczających błot i wysypisk śmieci, tworzących dwa odmienne pola walki, w których podmiot miota się, poszukując dalekiego i wyniosłego wewnętrznego zamku - którego forma [...] wyjątkowo wyraziście symbolizuje Id. Podobnie w myśleniu można znaleźć istnienie takich samych fortyfikujących struktur, która to metafora pojawia się spontanicznie, jak gdyby wywiedziona z samych symptomów, dla oznaczenia mechanizmów nerwicy obsesyjnej: odwrócenia, izolacji, reduplikacji, anulacji, przemieszczenia ${ }^{13}$.

Ja idealne wyobrażane jest przez jednostkę jako rodzaj „fortecy” mającej je chronić przed „błotami i wysypiskami śmieci” roztaczajacymi się dookoła niego. Dlatego, jak stwierdzi później Lacan, Ja jest w ekonomii ludzkiego życia psychicznego symptomem obronnym, nie mającym "pozytywnego" uzasadnienia w sobie samym, ale jedynie uzasadnienie negatywne: jako forteca/obrona przed tym, co mu zagraża.

Ja idealne wyłania się dopiero $\mathrm{w}$ wyniku podjętej przez jednostkę próby ucieczki przed niszczącym ją podmywającym od wewnątrz, doświadczeniem "chaosu” siebie. Tylko dzięki wyobrażeniu siebie jako idealnej „obronnej fortecy” wyniesionej ponad grząskie bagna i śmietniki jednostka może uzyskać kontrolę nad własnym ciałem. Rozpoznaje je ona wówczas jako „potencjalną” jedność, nad której procesami i odruchami będzie mogła w przyszłości zapanować. Powoli to jej wkroczyć w przestrzeń kulturowo-społeczną jako Ja o trwałym poczuciu tożsamości siebie.

Nie wyklucza to sytuacji, kiedy ten proces nie dochodzi do skutku, względnie ulega zakłóceniom i deformacjom. Ja-forteca zostaje zburzona albo w ogóle się nie pojawia. Wtedy w relacji jednostki do siebie dominuje psychotyczne poczucie pokawałkowania własnego ciała, co prowadzi do ukształtowania się tożsamości rozchwianej, w której miejsce Ja idealnego zajmuje rozdęte omnipotentne Ja (Ja-Chrustus, Ja-Budda, Ja-Napoleon itd.).

4.

Ja idealne w ujęciu Lacana, wyobrażone na kształt obronnej fortecy, jest iluzją. Jest fikcyjnym obrazem siebie wytworzonym przez lustrzane od-

13 J. Lacan, Stadium lustra..., op. cit., s. 8. 
bicie, z którym jednostka się identyfikuje, obsadzając go narcystycznie. Drugą stroną tej identyfikacji jest wpisana w nią możliwość rozpadu, regresu na wczesne stadium doświadczenia własnego ciała jako pokawałkowanego. Postawa fascynacji owym Ja przeobraża się w postawę agresji wobec siebie lub innych, która ujawnia się w sytuacji, kiedy jednostka dostrzega jakąś rysę na idealnym obrazie siebie lub innego, z którym się identyfikuje. Dlatego Ja jest - jak powiada Lacan - symptomem, który pod wpływem zaistnienia określonych okoliczności może ulec rozpadowi. Następuje wówczas wybuch niepohamowanej agresji jednostki wobec siebie lub innych, co może prowadzić do samobójstwa lub do aktów mordu. Jednostka wpada w psychotyczny szał, tracąc całkowicie panowanie nad sobą, jak we wspomnianym przypadku sióstr Papin. Pod wpływem krytyki ze strony właścicielek domu w ich psychice nastąpił regres na poprzedzający "stadium lustra” etap doświadczenia własnego ciała jako pokawałkowanego, u podstaw którego stało traumatyczne doświadczenie jednej z sióstr bycia w dzieciństwie gwałconą przez ojca, „przejęte" na drodze projekcji przez drugą siostrę.

Lacan, nazywając w Stadium lustra ludzkie Ja symptomem, radykalizuje dokonaną przez Freuda krytykę autonomii ludzkiego Ja. Ten ostatni, mówiąc o Ja jako słudze, który nie bardzo wie, jak pogodzić ze sobą sprzeczne wymogi kierowane ku niemu przez Nad-Ja i To, przyznawał mu zarazem rodzaj autonomii. W jego ujęciu Ja było w ograniczonym zakresie samoistną instancją gdyż w odróżnieniu od dwóch pozostałych było nastawione na kierowanie się „zasadą rzeczywistości”. Podobne motywy obecne w pracach Freuda na temat Ja będzie rozwijać później Anna Freud oraz różne odmiany psychoanalizy amerykańskiej pod nazwą self-psychology.

Tymczasem w oczach Lacana Ja jako symptom nie posiada autonomii tego rodzaju. Jego pojawienie się w postaci "Ja idealnego" stanowi wyraz rozpaczliwej próby znalezienia jakiejś przeciwwagi dla doświadczenia przez dziecko własnego ciała jako chaosu poszczególnych części. Owa "przeciwwaga” jest jednak nikła i krucha, gdyż nie ma żadnej gwarancji tego, że wyłoniwszy się raz w fantazjach dziecka, owo Ja nie ulegnie już rozpadowi. Zmianę przyniesie dopiero uwzględnienie przez Lacana w późniejszym okresie „stabilizującej” roli porządku symbolicznego. Jest to jednak temat na inny artykuł.

5.

Zatrzymajmy się nieco dłużej nad sytuacja, w której dziecko jest skonfrontowane ze swoim odbiciem w lustrze. Jak już wspomniałem, Lacan nie twierdzi, że dziecko od razu rozpoznaje w nim obraz siebie. Najpierw rozpoznaje ono w nim jakieś „idealne” inne Ja, którym chciałoby 
być, gdyż - jak sobie wyobraża - pozwoliłoby mu to zdobyć kontrolę nad własnym „pokawałkowanym” ciałem. Dlatego rolę takiego idealnego innego Ja może równie dobrze spełnić obraz matki czy innej osoby, którą dziecko postrzega w otoczeniu. Aby przejść przez "stadium lustra", lustro nie jest człowiekowi w ogóle potrzebne. Lustro jest metafora, nazywa ten okres w życiu człowieka, w którym rolę idealnego obrazu siebie, będącego pierwowzorem dla rozwoju jego osobowości i wyobrażenia siebie jako Ja, może spełnić obraz ciała innego, którego postrzega.

Małe dziecko nie oddziela jeszcze wyraźnie obrazu innego siebie ujrzanego w lustrze od obrazu innego innego ujrzanego w otaczającym je świecie. Różnica ta zrazu nie jest dlań istotna, liczy się walor idealności tego obrazu, który sprawia, że niezależnie od tego, do kogo w sensie fizycznym on należy, dziecko bierze go za obraz siebie. Ten inny, którego widzę, to jestem Ja, bo takim właśnie chciałbym być. Dlatego zafascynowany tym obrazem zawłaszczam go dla siebie, staję się nim.

Świadczy o tym wymownie tranzytywizm dziecięcy ${ }^{14}$. Dziecko bije inne dziecko i płacze, tak jakby uderzało samo siebie. Dzieje się tak dlatego, ponieważ na tym etapie rozwoju dziecko nie odróżnia jeszcze swego "idealnego" obrazu od obrazu innych (np. od obrazu matki czy towarzyszy zabaw). Wszystkie te obrazy bierze zrazu za obrazy siebie. To zachowanie dziecka wynika stąd, że biorąc obraz innego dziecka za własny, nie może znieść tego, że nie panuje nad zachowaniami „tamtego". Ślad tej dziecięcej frustracji rozpoznajemy w irytacji dorosłego, który przeglądając się w lustrze, próbuje uczesać włosy, wymalować usta szminka, zgolić zarost, a "tamten" wykonuje podobne ruchy w dokładnie odwrotnym kierunku. Jeśli więc obraz ciała innego fascynuje dziecko, to dlatego, że prezentuje mu się jako upragniona przez nie idealna jedność, a nie dlatego, że jest to obraz ,jego" ciała ${ }^{15}$.

Dopiero z czasem dziecko zaczyna odróżniać lustrzany obraz siebie, własnego ciała, od obrazów innych, zyskując poczucie niezastępowanej indywidualności własnego Ja, o której pisze Plessner. Zarówno więc fascynacja dziecka obrazem ciała innego jak i jego frustracja, biorą sie stąd, że jego identyfikacja z tym obrazem ma zrazu postać całkowitą. Ten inny to Ja w sensie dosłownym, Ja niewymienialny na innego. Dlatego jeśli dziecko widzi obraz ciała matki, to ,,jest" ono tym ciałem, obraz ciała towarzysza zabaw, to ,jest" jego ciałem. Podobnie dosłowny stosunek ma dziecko do obrazu samego siebie ujrzanego w lustrze. Po drugiej stronie lustra zrazu nie ma nic.

14 Jacques Lacan powołuje się tu na rezultaty doświadczeń w szkole Charolotty Buhler, gdzie wykazano, jak dalece identyfikacja z imago innego wiąże się u dzieci z wybuchami zazdrości (J. Lacan, Stadium..., op. cit., s. 8).

15 Bardzo dobrze fenomen tranzytywizmu dziecięcego opisuje Hermann Lang w książce: idem, Język i nieświadomość, przeł. P. Piszczatowski, Gdańsk 2005. 
Codzienne doświadczenia pouczają jednak z czasem dziecko, że nie do końca tak jest. Wyciąga rękę do lustra, a tamten „inny” czyni to samo, tyle że jakby nie tą ręką; dotyka swego policzka, a tamten czyni to samo, tyle że jakby po drugiej stronie twarzy itd. Nie mówiąc już o „zachowaniach" innych, nad którymi dziecko zupełnie nie panuje. Stąd bierze się wspomniana agresja dziecka, które sfrustrowane dysharmonią między własnymi gestami a tym, jak się zachowuje ów lustrzany obraz siebie jako „innego", wyładowuje na nim całą swoją złość.

Ostatecznie stosunek dziecka do idealnego obrazu siebie jako Ja jest przepojony ambiwalencją. $Z$ jednej strony ten obraz jest dla niego źródłem narcystycznej auto-fascynacji, z drugiej zaś, zawierając w sobie element obcości, jest źródłem frustracji. W tej ambiwalencji stosunku do siebie można by dopatrywać się pewnej analogii do twierdzenia Kanta o "aspołecznej towarzyskości” człowieka, do którego nawiązuje Plessner. Według autora Krytyk bowiem człowiek: „[...] gnany ambicją żądzą władzy lub bogactwa, dąży do zdobycia sobie pozycji wśród bliźnich, których nie może znieść, ale bez których nie może się też obyć $[\ldots]^{16}$.

Plessner, rozwijając antropologiczne implikacje zawarte w tym ujęciu Kanta, wskazuje na to, że owo dążenie do zdobycia przez człowieka pozycji wśród innych ma swe źródło w fakcie, że:

"Gdziekolwiek" dana osoba się znajduje, to znaczy jakiekolwiek miejsce zajmuje w strukturze społecznej, tam może się znaleźć inna osoba, gdyż pozostają wzajemnie $\mathrm{w}$ stosunku zwierciadlanym. [...] najważniejsza jest tylko struktura wzajemności ugruntowana w osobowości jako takiej, struktura, która jedną osobę przyporządkowuje ściśle drugiej, bez względu na to, czym ona jest i co posiada ${ }^{17}$.

U podstaw Kantowskiego twierdzenia o „aspołecznej towarzyskości" człowieka tkwi określająca jego byt społeczny możliwość zajęcia przez każde Ja miejsca innego w stukturze społecznej. Człowiek, dążąc do kariery, bogactwa, może innych "nie znosić”, zajmować ich pozycje społeczne itd., niemniej jednak pozostaje z nimi już z góry w relacji zwierciadlanej wzajemności. Innymi słowy to, że potencjalnie każdy może w strukturze społecznej zając miejsce innego, stanowi warunek umożliwiający społeczną grę, w której każdy ma równe szanse. Tak pojęta "aspołeczność" ma swoją podstawę w "towarzyskości” człowieka, w tym, że w obrębie społeczeństwa pozostaje już w określonej relacji wzajemności z innymi.

16 I. Kant, Pomysty do ujęcia historii powszechnej w aspekcie światowym, przeł. I. Krońska, w: T. Kroński, Kant, Warszawa 1966, s. 179.

17 H. Plessner, Pytanie o..., op. cit., s. 288. 
Zwróćmy uwagę na założenia tej argumentacji. Inny mógłby wprawdzie zająć moje miejsce, gdyż jest w pewnym sensie takim samym Ja jak ja, ale ta możliwość substytucji dotyczy jedynie miejsca, jakie zajmuję w strukturze społecznej, a nie "miejsca” mnie jako Ja wziętego w indywidualnej konkretności mego bytu. Nie mam najmniejszego powodu, aby się obawiać, że inny zastąpi mnie jako Ja. Może on zastąpić mnie na stanowisku pracy, przejąć moje funkcje zawodowe, rodzinne, towarzyskie, ale nie może po prostu „wejść" we mnie i stać się moim Ja. Dlatego gdy dochodzi do przejęcia przez niego niektórych moich funkcji, nie ograbia mnie nigdy ze mnie samego, bo jest to ontologicznie niemożliwe. Zawsze mogę przy tym wycofać się w siebie, zmienić moje miejsce pracy itd. Zachowuję więc moje Ja w całym jego indywidualnym wymiarze. Jakkolwiek w wyniku tkwiącej u podstaw społecznego bytu "strukturalnej jednorodności” "Każdy mógłby być kimś innym..”, to jednak być nim „....nie może"18, gdyż ów byt - jak twierdzi Plessner określa sprzeczność między strukturą a faktycznością.

Chodzi tu o rozbieżność między dwoma wymiarami czy poziomami Ja. Z jednej strony jest to Ja związane z określoną społeczną funkcją jaką pełni, wzięte w swej abstrakcyjnej ogólności (Ja jako ojciec, mąż, urzędnik, profesor itd.) i może być w niej zastąpione przez każde inne Ja. W tej perspektywie owe inne Ja są przez człowieka postrzegane jako zagrożenie czy przeszkoda $\mathrm{w}$ realizacji jego celów. Z drugiej strony to Ja jednorazowe i niepowtarzalne, związane $\mathrm{z}$ partykularnym faktycznym bytem jednostki, która świadoma siebie posiada "osobowość" i jest jako taka niezastępowalna. Pewna wówczas tego, że nikt nie jest w stanie odebrać jej własnej „osobowości” (Ja indywidualne) i zająć jej „miejsca” w sensie dosłownym postrzega inne Ja jako niezbędny warunek społecznych "gier", jakie z nimi prowadzi, będąc raz w nich zwycięska, w innych przegrywając.

6.

W ujęciu Plessnera mamy zatem do czynienia z zupełnie innym aspektem odniesienia Ja do innego Ja niż ten, który ma na uwadze Lacan w Stadium lustra, pisząc o tranzytywizmie dziecięcym. Autor Pytania o conditio humana, nawiązując do Kantowskiej formuły ",aspołeczna towarzyskość", ma na względzie ambiwalencję odniesienia świadomego siebie, indywidualnego Ja do innych Ja na poziomie kulturowo-społecznym. Zakłada, że jest to Ja dojrzałe, w pełni świadome siebie, które może traktować siebie, własne ciało, innych, rzeczy tego świata jako przedmiot. Natomiast Lacan ma na uwadze "stadium” poprzedzające

18 Ibidem, s. 290. 
ukształtowanie się tak pojętego dojrzałego Ja. W stadium tym jednostka nie jest jeszcze w stanie odróżnić lustrzanego obrazu własnego ciała od obrazu ciała innego. Nie odróżnia też tego lustrzanego obrazu siebie od tego, kim jest ona realnie, po „tej” stronie lustra. Dlatego kiedy okazuje się, że ten lustrzany obraz siebie lub innego jest fikcyjnym innym Ja jednostki, rodzi to w niej frustrację i agresję. Staje ona przed problemem Narcyza, który musi rozstrzygnąć dylemat: albo Ja, albo On. Albo mój idealny obraz siebie w lustrze to jestem Ja wzięty w mojej realnej egzystencji, dlatego mogę się z nim utożsamić. Albo ten obraz to fikcja, gdyż należy do kogoś innego niż Ja, jest więc oszukańczą podróbką mojego obrazu. Dlatego muszę ją odrzucić, innego zaś, do którego on odsyła, należy unicestwić. Ponieważ ów „inny” w lustrze to fikcyjny obraz samego Narcyza, ten unicestwiając tę fikcję, unicestwia samego siebie. Ten jego akt jest tożsamy z wybuchem psychozy, której podmiot, chcąc zniszczyć swego „innego", całą agresję kieruje przeciwko sobie. I ta możliwość, jako możliwość autodestrukcji - chociaż psychotyk swoją agresję może równie dobrze skierować przeciwko innemu - zakorzeniona jest w wyobrażeniu przez człowieka siebie jako Ja.

Inaczej niż przyjmuje to wyrastający z tradycji Kantowskiej Plessner, w oczach Lacana pojmowanie przez człowieka siebie jako Ja ma pierwotnie postać obsadzonego narcystycznie wyobrażenia siebie o statusie symptomu. Jako tego rodzaju symptom jest ono z jednej strony środkiem obronnym, "fortecą" w obliczu trudnego do zniesienia poczucia pokawałkowania własnego ciała. $Z$ drugiej strony jako tego rodzaju symptom owo Ja jest iluzja, wynikiem wyobcowania się jednostki wobec samej siebie. Rozpatrywane w świetle tej "genealogicznej" perspektywy nie stało się ono jeszcze samouzasadniającą się instancją o strukturze autorefleksyjnej. Dopiero kiedy jednostka zda sobie sprawę z tego, że jej własny lustrzany obraz pozostaje jako różna od niej "fikcja” w istotowym związku z nią samą (i tym różni się od obrazu innych Ja) i zaakceptuje tę "fikcję", możemy mówić o sytuacji, na którą wskazuje Kant, a za nim nawiązuje do niej Plessner. Jednostka może zacząć, zapominając o własnej genealogii, pojmować swoje Ja jako „wymienialne” z innymi Ja w przestrzeni społecznej, jeśli chodzi o pozycję, jaką zajmuje, zarazem jednak w swej indywidualności nie do zastąpienia przez inne Ja.

Nie znaczy to, że ujęcie Plessnera jest jedynie komplementarne wobec Lacanowskiego, odnosząc się do późniejszego etapu kształtowania się wyobrażenia Ja. I że różnice między nimi są jedynie funkcją tego, że obie te koncepcje koncentrują się na różnych stadiach kształtowania się wyobrażenia Ja. Bez wątpienia interesujący Plessnera etap, w którym jednostka kształtuje wyobrażenie siebie jako Ja, licząc się równocześnie z tym, że jakieś inne Ja może przejąć jej funkcje społeczne, w jakimś stopniu nadbudowuje się nad etapem "stadium lustra”. Antropologicznej perspektywie właściwej Plessnerowi umyka jednak nie tylko dramat 
doświadczania przez człowieka swego ciała, poprzedzający ukształtowanie się tego Ja. Nie bierze on również pod uwagę możliwości, że owo „stabilne”, w jakiejś mierze „wymienialne” z innymi Ja, może pod wpływem określonych okoliczności się rozpaść i zaniknąć. W rezultacie nastąpi jego regres na poziom quasi-psychotycznego doświadczenia własnego ciała jako pokawałkowanego. Ta możliwość nie jest jedynie wydarzeniem, do którego może dojść na poziomie ontycznym, lecz wpisana jest w sposób odniesienia się Ja do siebie. Ma ona charakter ontologiczny. Innymi słowy, ludzkie Ja może nie tylko brać udział w grach społecznych, pewne tego, że nikt w sensie dosłownym nie zajmie jego „miejsca”. Może ono równie dobrze ulec rozpadowi od wewnątrz i ta możliwośc wpisana jest $\mathrm{w}$ jego strukturę.

Ta różnica, rysująca się już wyraźnie w zestawieniu z wczesnymi pracami Lacana, bierze się stąd, że dla Plessnera paradygmatem myślenia o ludzkim Ja jest Ja neurotyka. A więc kogoś, kto jest w stanie poddać się rygorowi, jaki narzuca mu własne Ja idealne, wkraczając w przestrzeń społeczną jako podmiot zdolny do uczestniczenia w tworzących ją grach. Ten podmiot traktuje swoje Ja jako na poziomie społecznym wymienialne $z$ innymi Ja. Takie Ja zatem, akceptując to, że jest tylko jednym $\mathrm{z}$ wielu podmiotów społecznych gier, traktuje innych jako potencjalnych partnerów $w$ tych grach. Inni wprawdzie je ograniczają w jego społecznym bycie, mogą przejąć różne jego funkcje, ale bez nich gry społeczne nie miałyby sensu. Zarazem owo Ja jest pewne, że owe inne Ja nie są w stanie zastąpić je jako „osobowość". Jeśli owo Ja traktuje innych jako zagrożenie w realizacji własnych życiowych celów, to zarazem pewne jest siebie jako indywidualne Ja.

Tymczasem Lacan w swoich wczesnych pracach wskazuje na możliwość innego ukształtowania się struktury ludzkiej tożsamości, w której nie dochodzi do pojawienia się pojęcia Ja „wymienialnego" z innymi i zarazem poczucia jego niezastępowalności jako indywidualnego. Ja traktuje wówczas już samo istnienie innych Ja jako śmiertelne zagrożenie dla niego. W żadnym aspekcie swego społecznego bytu nie może ono ich uznać jako ze sobą „,wymienialnych", gdyż odnosi się do nich zgodnie z dualistyczna, narcystyczną logiką wyłączności: albo Ja, albo On. Jego relacja do nich jest relacją walki na śmierć i życie i może zostać rozwiązana jedynie poprzez zniszczenie jednej ze stron.

\section{Bibliografia}

Dybel P., Urwane ścieżki, Kraków 2001.

Kant I., Pomysty do ujęcia historii powszechnej w aspekcie światowym, przeł. I. Krońska, w: T. Kroński, Kant, Warszawa 1966. 
Lacan J., Stadium lustra, przeł. J. Aleksandrowicz, „Psychoterapia”, 1987, nr 4.

Lacan J., De la psychose paranoiaque dans ses rapports avec la personnalite, Paris 1932.

Lacan J., Ecrits, Paris 1960.

Plesssner H., Pytanie o conditio humana, przeł. Z. Krasnodębski i in., Warszawa 1988.

Roudinesco E., Lacan. Jego życie i myśl, przeł. R. Reszke, Warszawa 2005.

Scheler M., Pisma z antropologii filozoficznej i teorii wiedzy, przeł. S. Czerniak Warszawa 1987.

\section{Streszczenie}

\section{Człowiek, zwierzę i zwierciadło. Genealogia ludzkiego Ja według Helmutha Plessnera i Jacquesa Lacana}

W artykule porównuję ze sobą koncepcję ludzkiego Ja Helmutha Plessnera tkwiącą u podstaw jego antropologii filozoficznej oraz wczesną teorię „, stadium lustra" Jacquesa Lacana. Obaj autorzy powołują się na eksperyment Köhlera, który polegał na obserwacji odmiennej reakcji dziecka i szympansa na swój lustrzany obraz. Wyciagają jednak z tego odrębne ontologiczne konsekwencje. Plessner twierdzi, że dziecko, rozpoznając obraz w lustrze jako własny i kształtując wyobrażenie siebie jako Ja, dopuszcza możliwość jego zastąpienia przez inne Ja na poziomie funkcji społecznych, jakie pełni. Zarazem jednak wie, że $\mathrm{w}$ sensie dosłownym nikt jego indywidualnego Ja nie zastąpi. Lacan natomiast twierdzi, że wyobrażenie siebie jako Ja jest symptomem obronnym, który stanowi alternatywę dla poczucia pokawałkowania własnego ciała, doświadczanego przez dziecko w najwcześniejszej fazie swego życia (tzw. Ja idealne). To wyobrażenie przy tym nie jest czymś, co raz ustalone, jest dane raz na zawsze, ale podlega groźbie rozpadu i regresu na ten wczesny etap. Wymownie świadczy o tym passage au acte $\mathrm{w}$ przypadku psychotyków, w którym w wybuchu niepochamowanej agresji następuje całkowity rozpad Ja. Tę możliwość rozpadu Ja, względnie przyjęcia przez nie patologicznie rozdętej postaci, jak w przypadku psychotyków, zapoznaje Plessner w swojej koncepcji.

Słowa kluczowe: Ja, Ja idealne, rozczłonkowane ciało, lustrzane odbicie, psychoza, narcyzm, osobowość 


\section{Summary}

\section{Man, animals and mirror. Genealogy of the human self according to Helmuth Plessner and Jacques Lacan}

In the article I compare Helmuth Plessner's concept of the human I that underlies his philosophical anthropology and the theory of "mirror stage” by Jacques Lacan. They have both been inspired by Köhler's experiment in which an examined child and a chimpanzee reacted differently to their images in the mirror. Yet, Plessner and Lacan drew different conclusions from that experiment. Plessner maintained that the child who recognizes the image in the mirror as its own takes into account the possibility of its replacement by another I on the level of the social roles and functions it plays. Yet, at the same time, it is very well aware that nobody will be able to replace its own individual I. While Lacan says the ideal image of the I bears the status of the defence-symptom that represents an alternative to the feeling of the dismembered body that the child experiences in the early phase of its life. This image of the I is not given forever but is always endangered by the possibility of destruction and regress on its early stage of the dismembered body. The telling testimony of this is the passage au acte by psychotics in which the outburst of aggression is accompanied by the destruction of the I. Or the cases in which the I assumes the pathologically exaggerated shape. This possibility of the destruction of the I that is inherently rooted in its structure has been misrecognized by Plessner.

Keywords: I, ideal I, dismembered body, mirror image, psychosis, narcissism, personality 